\title{
Raloxifen Prevents Bone Loss in Castrated Male Mice
}

\author{
P. D. BROULÍK, K. BROULÍKOVÁ \\ Third Medical Clinic, First Medical Faculty, Charles University, Prague, Czech Republic
}

Received April 11, 2006

Accepted June 30, 2006

On-line available August 22, 2006

\begin{abstract}
Summary
Raloxifen is a selective estrogen receptor modulator which prevents bone loss in ovariectomized female mice in a fashion similar to estrogens. Since testosterone-deficient male mice also lose bone mass, we were interested in testing the effects of raloxifen on bones in intact and castrated male mice. Bone density was significantly reduced in castrated animals $(1.36 \pm 0.04 \mathrm{~g} / \mathrm{ml})$ as compared to intact animals $(1.42 \pm 0.03 \mathrm{~g} / \mathrm{ml})(\mathrm{p}<0.01)$. When castrated mice with extraordinarily low concentrations of testosterone and with reduced weight of seminal vesicles were treated with raloxifen, the changes in bone density and bone minerals resulting from castration $(1.36 \pm 0.04 \mathrm{~g} / \mathrm{ml})$ were entirely prevented $(1.40 \pm 0.01 \mathrm{~g} / \mathrm{ml})$. Cortical bone was lost in orchidectomized mice, and this decrease in cortical thickness of the femur was prevented by raloxifen administration. Raloxifen in a dose used in humans for treatment of osteoporosis decreased the weight of seminal vesicles, an organ which is highly sensitive to the androgenic effect, decreased the concentration of testosterone $(12.5 \pm 2.8 \mu \mathrm{mol} / \mathrm{l})(\mathrm{p}<0.01)$ but not to the same level as in the case of castrated animals $(0.6 \pm 0.3 \mu \mathrm{mol} / 1)$, and did not have any effect on bone density or mineral content in intact mice. The results of the present study may thus be interpreted as supporting the hypothesis that raloxifen is an effective agent against the deleterious effects of castration-induced osteopenia in male mice and also support the hypothesis that estrogens may have physiological skeletal effects in male mice.
\end{abstract}

\section{Key words}

Orchidectomy $\bullet$ Bone density $\bullet$ Raloxifene $\bullet$ Male mice

\section{Introduction}

It is well established that androgens exert marked effects on bone homeostasis. Orchidectomy in mature male mice results in a rapid development of osteopenia in the femur. The surgically castrated animals are widely used as a model of bone loss due to androgen deficiency (Wink and Fetts 1980) Recent findings of the role of estrogen receptors in the bone as demonstrated in experimental and clinical observations in estrogen receptor deficiency favor the hypothesis that androgens may influence the bone tissue predominantly after aromatization to estrogens (Vanderschuren et al. 1997). Several lines of evidence implicate estrogen deficiency as a cause of bone loss in elderly men. Raloxifen is a selective estrogen receptor modulator from the benzothiophene class that binds to the estrogen receptor with a high affinity. Raloxifen, a selective estrogen receptor modulator (SERM), has estrogen-agonist effects on bone but is not feminizing (Doran et al. 2001) Since the effect of testosterone on bone in men may partly be mediated by estradiol the skeletal actions of raloxifen in men are of interest (Amin 2003).

As far as we are aware, there is no previous 
report on long-term effects of raloxifen on adult male mice. In order to test the hypothesis that raloxifen may protect against bone loss in castrated male mice, we have used the orchidectomized mouse model.

\section{Materials and Methods}

Adult male mice of strain $\mathrm{H}$ (Velaz Prague) weighing approximately $30 \mathrm{~g}$ were used for the experiments. They were fed a standard laboratory diet containing $23 \%$ protein, $1.2 \%$ calcium and $0.6 \%$ phosphorus with water ad libitum, and were kept in an indirectly illuminated room with controlled temperature $\left(24 \pm 2{ }^{\circ} \mathrm{C}\right)$. The animals were divided into four groups of 8 animals each: 1) intact controls, 2) intact animals fed raloxifene for 3 months, 3) animals 3 months after castration, and 4) castrated mice fed raloxifene for 3 months. Raloxifene (Elli Lilly Evista) was mixed to the diet and consumed in a dose $5.0 \mathrm{mg} / \mathrm{kg} /$ day for 3 months. We used the dose, which is considered to be comparable to a dose of raloxifen used for treatment of osteoporosis in women. Such a dose has also been used by Al Jamal and Dubin (2000). The animals were weighed before and after the experiment and their food consumption was measured daily, including the drug in a dose indicated above. When the animals were killed, blood was withdrawn from the heart, seminal vesicles and femurs were removed, cleaned and weighed on a torsion balance.

The femurs were isolated, cleaned of soft tissues, the marrow elements were flushed out with cold saline through a needle inserted into the marrow cavity and finally the bone was weighed and placed in an unstoppered glass vial filled with deionized water and then was placed into a desiccator. The bones were suspended on a fine wire mesh and weighed in air and in water to an accuracy of $0.1 \mathrm{mg}$. The volume and density of the femurs were calculated from the mass in air and water by Archimedes principle (Kalu et al. 1994). The bones were then dried to constant weight and incinerated for $24 \mathrm{~h}$ at $600{ }^{\circ} \mathrm{C}$ to white ash which was weighed. The ash weight was expressed per milliliter of volume of unashed femur. Bone ashes were then dissolved in $3 \mathrm{~mol} / \mathrm{l}$ hydrochloric acid before the determination of calcium and phosphorus content.

Calcium was measured by the method of Gitelman (1967) and phosphorus according to Kraml (1966). Testosterone in the blood plasma was determined by conventional radioimmunoassays (CIBA-Corning Diagnostic Corp.).
For the bone morphology we used the method presented by Beall et al. (1984) and (Vanderschueren et al. (1992). The left femurs were also removed and cleaned of tissue for X-ray examination. Standardized roentgenographs of the femur were made using Philips Mamo Diagnost 3000 X-ray machine at controlled exposures of $26 \mathrm{kV}$ at $5.5 \mathrm{~mA}$. Morphometric measurements were performed directly on the $\mathrm{X}$ rays after magnification with a fine caliper. On the roentgenographs at $40 \%$ of the total length starting from the distal end, the outer and inner bone diameters and cortical width were measured after magnification with the fine caliper. Seminal vesicles were cleaned and weighed and the weight was expressed in relative values (mg/100 g b. wt).

Differences between groups were determined statistically by analysis of variance followed by Duncan's multiple range test (Duncan 1955).

\section{Results}

The effects of castration and raloxifen administration on all groups of animals are summarized in Table 1. We did not find any differences in body weight after castration and raloxifen had also no significant effect on body weight. Serum calcium and phosphate concentration were normal and did not vary between the groups. Significant changes were observed in the weight of seminal vesicles, namely a striking decrease of seminal vesicles weight was found in orchidectomized mice $(49.7 \pm 3.2 \mathrm{mg} / 100 \mathrm{~g}$ b.wt). The administration of raloxifen to castrated mice did not produce any changes in the weight of seminal vesicles.

As expected plasma testosterone was decreased in castrated mice $(0.5 \pm 0.2 \mu \mathrm{mol} / \mathrm{l})$. Seminal vesicles weight $(406 \pm 72 \mathrm{mg} / 100 \mathrm{~g}$ b.wt) and plasma testosterone levels $(12.5 \pm 2.8 \mu \mathrm{mol} / \mathrm{l})$ were significantly lower in intact animals treated with raloxifen, but remained higher than the seminal vesicles weight and plasma testosterone levels of castrated animals $(49.7 \pm 3.2 \mathrm{mg} / 100 \mathrm{~g}$ b.wt; $0.5 \pm 0.2 \mu \mathrm{mol} / \mathrm{l})(\mathrm{p}<0.01)$

Bone density, ash and mineral content of the femur were significantly decreased in orchidectomized mice $(1.36 \pm 0.04 \mathrm{~g} / \mathrm{ml})$ compared with untreated animals $(1.42 \pm 0.03 \mathrm{~g} / \mathrm{ml})$. The decrease in bone density and mineral content in the orchidectomized mice was completely prevented by treatment with raloxifen $(1.40 \pm 0.01 \mathrm{~g} / \mathrm{ml})$. The administration of raloxifen to intact mice did not cause a significant increase in bone 
Table 1. Variables of body weight, bone density, bone mineral content, plasma testosterone and seminal vesicles weight in individual groups of animals.

\begin{tabular}{lcccc}
\hline & Intact & Castrated & Intact + Raloxifene & Castrated + Raloxifene \\
\hline Initial body weight $(\mathrm{g})$ & $30.2 \pm 1.0$ & $31.3 \pm 1.0$ & $31.5 \pm 0.9$ & $30.6 \pm 1.2$ \\
Final body weight $(\mathrm{g})$ & $48.2 \pm 4.0$ & $42.1 \pm 2.5$ & $45.8 \pm 3.0$ & $42.3 \pm 2.5$ \\
Volume of femur $(\mu \mathrm{l})$ & $64.0 \pm 7$ & $53.5 \pm 5$ & $53.8 \pm 5$ & $55.3 \pm 3$ \\
Density of femur $(\mathrm{g} / \mathrm{ml})$ & $1.422 \pm 0.03$ & $1.361 \pm 0.04^{*}$ & $1.419 \pm 0.03$ & $1.400 \pm 0.01$ \\
Ash content $(\mathrm{g} / \mathrm{ml})$ & $0.532 \pm 0.04$ & $0.484 \pm 0.04^{*}$ & $0.518 \pm 0.03$ & $0.552 \pm 0.05$ \\
Calcium $(\mathrm{mg} / \mathrm{ml})$ & $202.2 \pm 6.0$ & $184.2 \pm 5.0^{*}$ & $195.0 \pm 4.0$ & $206 \pm 5.0$ \\
Phosphate $(\mathrm{mg} / \mathrm{ml})$ & $91.4 \pm 3.0$ & $82.3 \pm 3.7^{*}$ & $87.2 \pm 3.0$ & $92.1 \pm 4.0$ \\
Seminal vesicle $(\mathrm{mg} / 100 \mathrm{~g}$ b.wt) & $558 \pm 124$ & $49.7 \pm 3.2 *$ & $406 \pm 72 *$ & $52.3 \pm 1.1^{*}$ \\
Plasma testosterone $(\mu \mathrm{mol} / \mathrm{l})$ & $24.0 \pm 3.8$ & $0.5 \pm 0.2^{*}$ & $12.5 \pm 2.8 *$ & $0.6 \pm 0.3 *$ \\
Plasma calcium $(\mathrm{mmol} / \mathrm{l})$ & $2.3 \pm 0.08$ & $2.2 \pm 0.06$ & $2.2 \pm 0.05$ & $2.3 \pm 0.08$ \\
Plasma phosphate $(\mathrm{mmol} / \mathrm{l})$ & $4.1 \pm 0.1$ & $4.2 \pm 0.2$ & $4.2 \pm 0.1$ & $4.2 \pm 0.1$ \\
\hline
\end{tabular}

Data are means \pm S.D. $(n=8) .{ }^{*} p<0.01$ vs. intact animals

Table 2. Morphometric variables $(\mathrm{mm})$ determined on femur in individual groups of animals.

Intact Castrated Intact + Raloxifen Castrated + Raloxifen

\begin{tabular}{|c|c|c|c|c|}
\hline Femur length & $17.4 \pm 0.3$ & $17.2 \pm 0.3$ & $17.4 \pm 0.4$ & $17.3 \pm 0.3$ \\
\hline Outer diameter & $2.14 \pm 0.07$ & $2.11 \pm 0.09$ & $2.13 \pm 0.05$ & $2.14 \pm 0.03$ \\
\hline Inner diameter & $1.62 \pm 0.12$ & $1.84 \pm 0.13 *$ & $1.64 \pm 0.13$ & $1.65 \pm 0.11$ \\
\hline Cortical width & $0.52 \pm 0.02$ & $0.27 \pm 0.02 *$ & $0.49 \pm 0.03$ & $0.49 \pm 0.04$ \\
\hline
\end{tabular}

Data are means \pm S.E.M. $(n=8)$. $* p<0.01$ vs. intact animals

density, the ash and mineral content of the femur, compared to that in untreated animals. Femoral length and outer diameter were not significantly different between the groups 3 months after orchidectomy. At this time, however, orchidectomized mice had significantly thinner cortical width. The decrease in cortical widths was prevented by the administration of raloxifene.

\section{Discussion}

The present results confirm the well-known fact that castration leads to osteopenia in experimental animals. An extraordinary responsiveness to the withdrawal or administration of androgens can be demonstrated in mice. The bones of our castrated mice were characterized by a reduction of bone density and ash as well as by lower calcium and phosphorus content.

When castrated mice with low concentrations of testosterone and weights of seminal vesicles were treated with raloxifene, the changes in bone density resulting from castration were entirely prevented. The decrease in cortical thickness in orchidectomized mice was prevented by raloxifene treatment. At the concentration studied, raloxifene exerted a potent estrogenic activity on bone resorption and a moderate effect on the weight of seminal vesicles and plasma testosterone in intact mice.

We have used a dose which is considered to be comparable to a dose of $60 \mathrm{mg}$ raloxifene used in the treatment of osteoporosis in women and which was used in our experiments (Al Jamal and Dubin 2000). However, this treatment might not reflect the pharmacological and physiological conditions in humans. All mice in our experiment remained healthy throughout the experiment, consumed their food ration daily and showed no significant weight changes.

Pharmacological therapy with the estrogen agonist raloxifene in castrated mice supports the hypothesis that estrogens may also have physiological skeletal effects in male mice. Many arguments favor the hypothesis that the androgen action on bone could depend 
on the aromatization of androgens into estrogens. Treatment with 17-beta estradiol, but not with testosterone, in two men with the aromatase gene mutation resulted in an increase in bone mineral density (Gennari et al. 2004), whereas treatment with 17-beta estradiol, or testosterone, was ineffective in a man who had no functional estrogen receptor due to a premature stop codon in the estrogen receptor gene (Smith et al. 1994. Herrmann et al. 2002). Treatment with 17-beta estradiol decreased the levels of bone turnover markers in healthy elderly men and in patients who had been orchidectomized due to prostatic cancer (Taxel et al. 2000). Szulc et al. (2001) also suggested that 17-beta estradiol is the most potent determinant of bone mineral density among sexual steroids in men.

Bone cells contain not only estrogen receptors (Nilsson et al. 1999) but also enzymes of sex steroid pathways such as aromatase and 17-beta hydroxysteroid dehydrogenase (Scopacasa et al. 2000). Raloxifen, which is an estrogen antagonist for the breast, is an estrogen agonist for the skeleton (Riggs and Hartmann 2003).

Several lines of evidence implicate estrogen deficiency as a cause of bone loss in elderly men. In healthy middle-aged men, raloxifene treatment has been associated with increased serum estradiol and with decreased biochemical markers of bone turnover (Uebelhart et al. 2004).

Raloxifene treatment of intact male rats for 14 and 28 days produced a significant dose-dependent regression of ventral prostate and seminal vesicles (Steiner et al. 2001). Raloxifene exerts the effects on bone in the mice that are similar to those of estradiol. Raloxifene replacement in androgen-deficient adult male mice prevents bone loss.

These pilot data support the theoretical usefulness of the selective estrogen receptor modulators as a therapeutic regimen for male osteoporosis. Our findings with raloxifene are consistent with the reported effects of another selective estrogen receptor modulator tamoxifen on bone in male mice (Broulík 2000).

The results of the present study may be interpreted as supporting the hypothesis that raloxifene is an effective agent against the deleterious effects of castration-induced osteopenia in male mice. Furthermore, the estrogens may also have physiological skeletal effects in male mice.

\section{Acknowledgements}

This work was supported by a grant from the Czech Ministry of Health IGA-MZ 7508.

\section{References}

AL JAMAL JH, DUBIN NH: The effect of raloxifen on the uterus weight response in immature mice exposed to 17 beta-estradiol, 1,1,1-tri chloro-2,2 bis (p-chlorophenyl) ethane and methoxychlor. Am J Obstet Gynecol 182: 1099-1102, 2000.

AMIN S: Male osteoporosis: epidemiology and pathophysiology. Curr Osteoporosis Rep 1: 71-77, 2003.

BEALL PT, MISRA LK, YOUNG RL, SPJUT HJ, EBAVANS HJ, Le BLAME A: Clomiphene protects against osteoporosis in the mature ovariectomized rat. Calcif Tissue Int 36: 123-125, 1984.

BROULIK PD: Tamoxifen prevents bone loss in castrated male mice. Horm Metab Res 32: 181-184, 2000.

DORAN PM, RIGGS BL, ATKINSON EJ, KHOSLA S: Effects of raloxifene a selective estrogen receptor modulator on bone turnover markers and serum sex steroid and lipid levels in elderly men. J Bone Miner Res 16: 21182125, 2001.

DUNCAN D: Multiple range and multiple F test. Biometrics 11: 1-4, 1955.

GENNARI L, NUTI R, BILEZIKIAN JP: Aromatase activity and bone homeostasis in men. J Clin Endocrinol Metab 89: 5898-5907, 2004.

GITELMAN H: An improved automated procedure for the determination of calcium in biological specimens. Anal Biochem 18: 521-531, 1967.

HERRMANN BL, SALLER B, JANSSEN OE, GOCKE P, BOCKISCH A, SPERLING H, MANN K, BROECKER M: Impact of estrogen replacement therapy in a male with congenital aromatase deficiency caused by a novel mutation in the CYP19 gene. J Clin Endocrinol Metab 87: 5476-5488, 2002.

KALU DN, HARDIN RR, CECKERHAM R: Evaluation of the pathogenesis of skeletal changes in ovariectomized rats. Endocrinology 115: 507-511, 1994.

KRAML J: A semiautomated determination of phospholipids. Clin Chim Acta 13: 442-448, 1966. 
NILSSON LO, BOMAN A, SAVENDAHL L, GRIGELIONIENE G, OHLSSON C, RITZEN EM, WROBLEWSKI J: Demonstration of estrogen receptor beta immunoreactivity in human growth plate cartilage. J Clin Endocrinol Metab 84: 370-373, 1999.

RIGGS BL, HARTMANN LC: Selective estrogen receptor modulators mechanisms of action and application to clinical practice. N Engl J Med 348: 618-629, 2003.

SCOPACASA F, HOROWITZ M, WISHART JM, MORRIS HA, CHATTERTON BE, NEED AG: The relation between bone density, free androgen index, and estradiol in men 60 to 70 years old. Bone 27: 145-149, 2000.

SZULC P, MUNOZ F, CLAUSTRAT B, GARNERO P, MARCHAND F, DUBOEUF F, DELMAS PD: Bioavailable estradiol may be an important determinant of osteoporosis in men: the MINOS study. J Clin Endocrinol Metab 86: 192-199, 2001.

SMITH EP, BOYD J, FRANK GR, TAKAHASHI RM, COHEN B, SPECKER TC, WILLIAMS TC, LUBHAN DB, KORACH KS: Estrogen resistance caused by a mutation in the estrogen-receptor gene in a man. $N$ Engl J Med 331: 1056-1061, 1994.

STEINER MS, RAGHOW S, NEUBAUER BL: Selective estrogen receptor modulators for the chemoprevention of prostate cancer. Urology 57 (Suppl 1): 68-72, 2001.

TAXEL P, KENNEDY D, FALL P, WILLARD A, SHOUKRI J, CLIVE J, RAISZ LG: The effect of short-term treatment with micronized estradiol on bone turnover in older men with low bone mass. Endocr Res 26: 381$398,2000$.

UEBELHART B, HERRMANN F, PAVO I, DRAPER MW, RIZZOLI R: Raloxifene treatment is associated with increased serum estradiol and decreased bone remodeling in healthy middle aged men with low sex hormone levels. J Bone Miner Res 19: 1518-1524, 2004.

VANDERSCHUEREN D, VAUTTERCK AMH, SUIKER WJ, WISSER LPC, SCHOT R, BOUILLON R: Bone and mineral metabolism in aged male rats. Short and long term effects of androgen deficiency. Endocrinology 130: 2906-2916,1992.

VANDERSCHUEREN D, VAN HERCK E, NIJS J, EDERVEEN AG, DE COSTER R, BOUILLON R: Aromatase inhibition impairs skeletal modeling and decreases bone mineral density in growing male rats. Endocrinology 138: 2301-2307, 1997.

WINK CS, FETTS WJL: Effects of castration on the bone structure of male rats. A model of osteoporosis. Calcif Tiss Int 32: 77-82, 1980.

\section{Corresponding author}

P. D. Broulík, Third Medical Clinic, First Medical Faculty, Charles University, Prague, Czech Republic, U Nemocnice 1, 12808 Prague 2, Czech Republic. E-mail: pbrou@lf1.cuni.cz 